\title{
Improved Oil Recovery in Fluvial Dominated Deltaic Reservoirs of Kansas - Near-Term
}

\author{
Quarterly Report \\ January 1 - March 31, 1998
}

\author{
By: \\ D. W. Green; G. P. Willhite; A. Walton; D. McCune \\ R. Reynolds; M. Michnick; L. Watney
}

\author{
Work Performed Under Contract No.: DE-FC22-93BC14957 \\ For \\ U.S. Department of Energy \\ Office of Fossil Energy \\ Federal Energy Technology Center \\ P.O. Box 880 \\ Morgantown, West Virginia 26507-0880
}

By

The University of Kansas Center for Research, Inc.

Lawrence, Kansas 66045 


\section{Disclaimer}

This report was prepared as an account of work sponsored by an agency of the United States Government. Neither the United States Government nor any agency thereof, nor any of their employees, makes any warranty, express or implied, or assumes any legal liability or responsibility for the accuracy, completeness, or usefulness of any information, apparatus, product, or process disclosed, or represents that its use would not infringe privately owned rights. Reference herein to any specific commercial product, process, or service by trade

name, trademark, manufacturer, or otherwise does not necessarily constitute or imply its endorsement, recommendation, or favoring by the United States Government or any agency thereof. The views and opinions of authors expressed herein do not necessarily state or reflect those of the United States Government or any agency thereof. 
The U niversity of K ansas Center for Research, Inc.

A pril 15, 1998

Budget Period \#1 Duration from 06/18/93 - 03/31/95

Budget Period \#2 D uration from 04/01/95 - 12/31/98

DOE A ward \$2,007,446

$$
\begin{gathered}
\text { Program M anager } \\
\text { Don W. Green } \\
\text { University of Kansas } \\
\text { L awrence, Kansas }
\end{gathered}
$$

Principal Investigators

Don W. Green

G. Paul Willhite

Co-Investigators

A. W alton, D. M cCune, R. Reynolds, M. M ichnick, L. Watney

DOE Project Officer

Rhonda P. Lindsey

Bartlesville Project Office

Reporting Period 01/01/98 - 03/31/98

(19th Quarterly Report)

"U.S./DOE PATENT CLEARANCE IS NOT REQUIRED 


\section{Objectives}

The objective of this project is to address waterflood problems of the type found in M orrow sandstone reservoirs in southwestern K ansas and in Cherokee Group reservoirs in southeastern K ansas. Two demonstration sites operated by different independent oil operators are involved in this project. The Stewart Field is located in Finney County, Kansas and is operated by PetroSantander, Inc. The N elson L ease is located in Allen County, Kansas, in the N.E. Savonburg Field and is operated by James E. Russell Petroleum, Inc.

General topics to be addressed are 1) reservoir management and performance evaluation, 2) waterflood optimization, and 3) the demonstration of recovery processes involving off-the-shelf technologies which can be used to enhance waterflood recovery, increase reserves, and reduce the abandonment rate of these reservoir types.

In the Stewart Project, the reservoir management portion of the project conducted during Budget Period 1 involved performance evaluation. This included 1) reservoir characterization and the development of a reservoir database, 2) volumetric analysis to evaluate production performance, 3) reservoir modeling, 4) laboratory work, 5) identification of operational problems, 6) identification of unrecovered mobile oil and estimation of recovery factors, and 7) identification of the most efficient and economical recovery process.

To accomplish these objectives the initial budget period was subdivided into three major tasks. The tasks were 1) geological and engineering analysis, 2) laboratory testing, and 3) unitization. Due to the presence of different operators within the field, it was necessary to unitize the field in order to demonstrate a field-wide improved recovery process. This work was completed and the project moved into Budget Period 2.

Budget Period 2 objectives consisted of the design, construction, and operation of a field-wide waterflood utilizing state-of-the-art, off-the-shelf technologies in an attempt to optimize secondary oil recovery. To accomplish these objectives the second budget period was subdivided into five major tasks. The tasks were 1) design and construction of a waterflood plant, 2) design and construction of a water injection system, 3) design and construction of tank battery consolidation and gathering system, 4) initiation of waterflood operations and reservoir management, and 5) technology transfer. Tasks 1-3 have been completed and water injection began in October 1995.

In the Savonburg Project, the reservoir management portion involves performance evaluation. This work included 1) reservoir characterization and the development of a reservoir database, 2) identification of operational problems, 3) identification of near wellbore problems such as plugging caused from poor water quality, 4) identification of unrecovered mobile oil and estimation of recovery factors, and 5) preliminary identification of the most efficient and economical recovery process i.e., polymer augmented waterflooding or infill drilling (vertical or horizontal wells).

To accomplish this work the initial budget period was subdivided into four major tasks. The tasks included 1) geological and engineering analysis, 2) waterplant optimization, 3) wellbore cleanup and pattern changes, and 4) field operations. This work was completed and the project has moved into Budget Period 2.

The Budget Period 2 objectives consisted of continual optimization of this mature waterflood in an attempt to optimize secondary and tertiary oil recovery. To accomplish these objectives the second budget period is subdivided into six major tasks. The tasks were 1) waterplant development, 2) profile modification treatments, 3) pattern changes, new wells and wellbore cleanups, 4) reservoir development (polymer flooding), 5) field operations, and 6) technology transfer. 


\section{Summary of Technical Progress}

\section{Stewart Field Project}

\section{Task II.1 - Design/C onstruct W aterflood Plant}

$\underline{\text { Summary of work in last quarter }}$

Installed a horizontal injection pump to increase the injection capacity from approximately 9,900 to 15,000 BW PD. Current injection rate is 10,200 BW PD.

Summary of planned work for next quarter

Review water supply sources for additional water with lower corrosivity.

\section{Task II. 2 - Design/C onstruct Injection System}

Summary of work in last quarter

In $\mathrm{M}$ arch, three additional wells were converted to injection to improve the sweep efficiency in several areas of the waterflood. These include the following wells:
Well
Comment
Haag Estate N 0.2
W as shut-in, currently injecting 500 BW PD.
Bulger 7-5
W as producing 4 BOPD, currently injecting 250 BWPD.
Bulger 7-10
W as producing < 1 BOPD, currently injection 250 BW PD.

Summary of planned work for next quarter

None planned.

\section{Task II.3 - Design/C onstruct Battery C onsolidation and G athering System}

Summary of work in last quarter

None.

$\underline{\text { Summary of planned work for next quarter }}$

None planned.

Task II.4 - Waterflood 0 perations and R eservoir M anagement

Summary of work in last quarter 
W ater supply well had significant downtime during $\mathrm{M}$ arch due to motor and cable burnout's. This resulted in 9 days of downtime.

Ongoing pump changes and speeding up pumping units were performed during the quarter on several wells. These changes are made as a result of the well testing program that identifies wells with production problems, rising fluid levels, abnormal production trends and low pump efficiencies. The changes that were made are a continued effort to maximize oil production and keep all the wells near a pumped off condition.

A pressure build-up test was performed on the M ackey No. 1 that indicated positive skin damage. An acid treatment was performed that resulted in a minor increase in production. Further evaluation will be conducted on a more aggressive treatment during the next quarter.

The computer model developed at the Tertiary Oil Recovery Project at the U niversity of Kansas has been revised to history match waterflood production and injection. This model will be used to simulate different scenarios to assist in reservoir management decisions in an attempt to maximize waterflood oil recovery.

Continued to monitor production and injection rates, water supply volumes, and injection pressures. Continued the ongoing testing of producing wells with test trailers and fluid level instruments. Ongoing allocation of the injection volumes in the injection wells were performed based on response in producers and injectors. Cumulative water injection through $M$ arch is 5,185,703 bbls. A verage daily production and injection rates for the field are displayed on the plot included with this report.

\section{Summary of planned work for next quarter}

Continue to monitor for response at producing wells with well tests and fluid levels. U pdate the reservoir computer model and simulate when applicable. U pgrade pumping equipment as necessary. Several increasing fluid levels will be addressed with larger pumping equipment and evaluation of additional progressive cavity pumps will be conducted.

Evaluation of three infill drilling locations will be conducted. These locations include south of the Pauls 9-1, southwest of the M eyer 10-4, and south/southeast of the M ackey \#4.

\section{Task II.5 - Technology Tranffer}

\section{Summary of work in last quarter}

Continued to publicize information on the success of the Stewart Field waterflood. O perators throughout the region continue to visit the field to view the state-of-the-art waterflood installation and computerized monitoring system.

\section{Summary of planned work for next quarter}

Continue to publicize information on the success of the Stewart Field waterflood. 


\section{Stewart Waterflood Average Daily Totals}

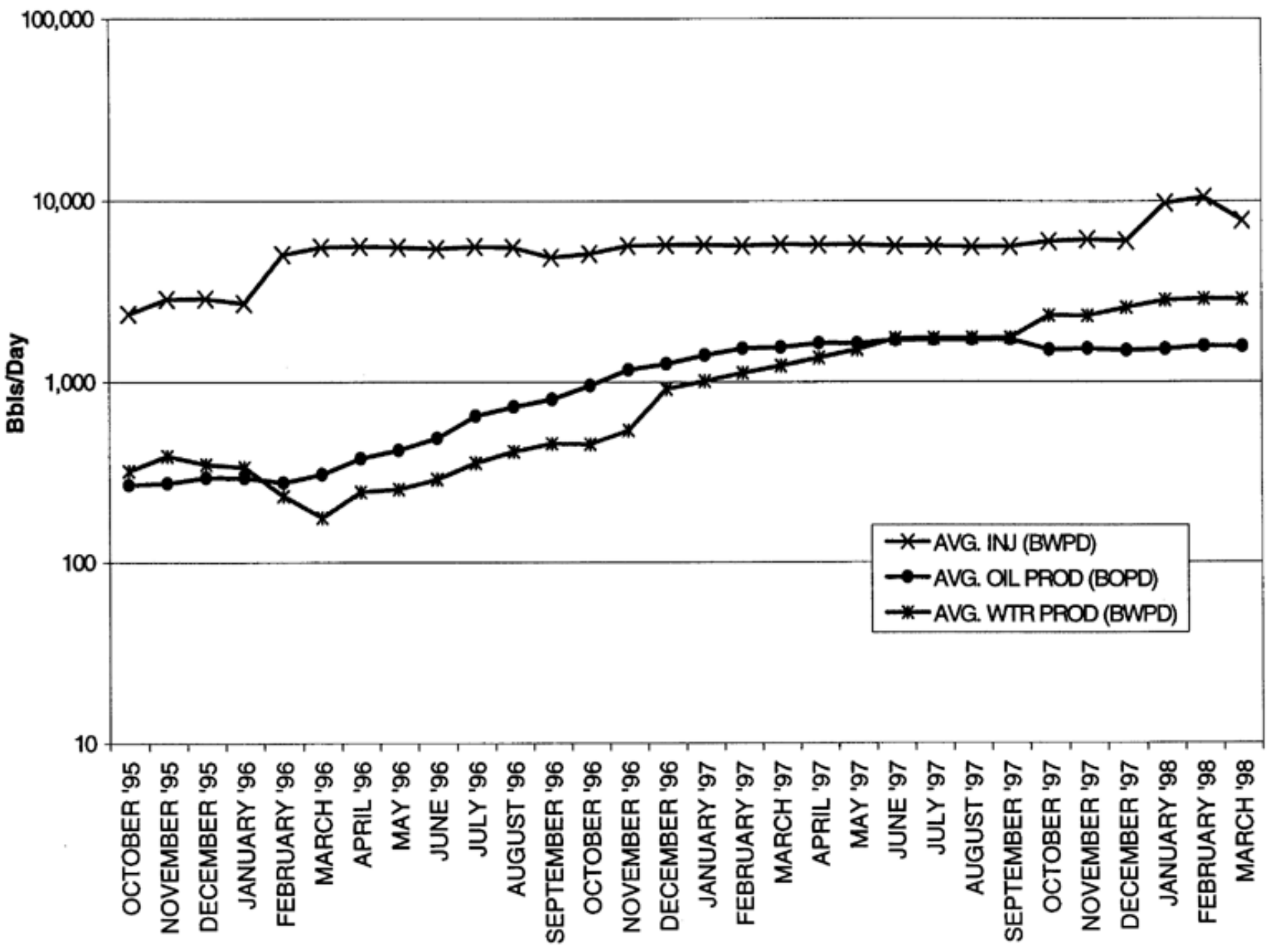




\section{Summary of Technical Progress}

\section{Savonburg Field Project}

\section{Task II.1 - Water Plant Development}

Summary of work in last quarter

In J anuary a series of various water treatment methods utilizing the air flotation unit (AFU) was initiated. Initially, all water-treating chemicals were removed, utilizing only the air injection. In February, a new water aeration compressor was installed and the slop tank and suction tanks were cleaned. Early in M arch the operator began adding bleach to the water. Two weeks later F LW-162, a flotation aid chemical was started and a chemical breaker was added to the stream on the last day of $M$ arch.

\section{Summary of work planned for next quarter}

The water treatment program will continue until all scenarios have had a sufficient time to be tested. A hydroclone will be added for solids removal.

\section{Task II.2 - Profile M odification T reatments}

Summary of work in last quarter

No channelblock treatments were performed during this quarter.

A pressure falloff test was attempted on well $0-1$, but was aborted due to equipment malfunction.

Temperature surveys were performed on wells RW -8 and RW -3. M echanical integrity tests were performed on wells RW -8 and RW-11.

Summary of work planned for next quarter

As soon as weather conditions allow wells RW - $1, \mathrm{RW}-3, \mathrm{RW}-6$ and RW -7 will have temperature surveys.

A $n$ attempt will be made to isolate the B3 zone in injection well $\mathrm{HW}-18$.

\section{Task II.3 - Pattern Changes and W ellbore Cleanup}

\section{Summary of work in last quarter}

The following wells were serviced during the last quarter; $\mathrm{H}-16$ (four times), $\mathrm{H}-20$ (twice), $\mathrm{K}-54$ (twice), H-30 (twice), H-22 (twice), K-44, K-10 and K-45. Service was required to repair pumps or replace joints of 1 " pump string that developed leaks. 
A nother attempt to recover the junk in $\mathrm{H}-27$ was unsuccessful.

W ells H-9 and KW-51 were plugged and abandoned in February.

Summary of planned work for next quarter

W ells will be tested, cleaned and worked on as needed.

\section{Task II.4 - R eservoir Development (Polymer Flooding)}

Summary of work in last quarter

W aiting on a decision to implement polymer flooding.

Summary of work for next quarter

Waiting on a decision to implement polymer flooding.

\section{Task II.5 - Field O perations}

Summary of work in last quarter

Normal field operations have included: 1) monitoring wells on a daily basis, 2) repairing waterplant, piping, and wells as required, 3) collecting daily rate and pressure data, and 4) solving any other daily field operational problem that might occur.

\begin{tabular}{ll} 
M onth & Oil Production \\
\cline { 2 - 2 } October 1993 & $26.4 \mathrm{~B} / \mathrm{D}$ \\
N ovember 1993 & \multicolumn{1}{c}{$30.7 \mathrm{~B} / \mathrm{D}$} \\
December 1993 & $32.0 \mathrm{~B} / \mathrm{D}$ \\
January 1994 & $30.8 \mathrm{~B} / \mathrm{D}$ \\
February 1994 & $30.9 \mathrm{~B} / \mathrm{D}$ \\
M arch 1994 & $30.3 \mathrm{~B} / \mathrm{D}$ \\
A pril 1994 & $29.1 \mathrm{~B} / \mathrm{D}$ \\
M ay 1994 & $28.5 \mathrm{~B} / \mathrm{D}$ \\
June 1994 & $30.3 \mathrm{~B} / \mathrm{D}$ \\
July 1994 & $28.9 \mathrm{~B} / \mathrm{D}$ \\
A ugust 1994 & $24.6 \mathrm{~B} / \mathrm{D}$ \\
October 1994 & $23.0 \mathrm{~B} / \mathrm{D}$ \\
N ovember 1994 & 25.7 B/D \\
December 1994 & $27.8 \mathrm{~B} / \mathrm{D}$ \\
January 1995 & $27.0 \mathrm{~B} / \mathrm{D}$ \\
February 1995 & $25.3 \mathrm{~B} / \mathrm{D}$ \\
M arch 1995 & $22.4 \mathrm{~B} / \mathrm{D}$ \\
A pril 1995 & $22.4 \mathrm{~B} / \mathrm{D}$ \\
M ay 1995 & $25.0 \mathrm{~B} / \mathrm{D}$ \\
June 1995 & $23.9 \mathrm{~B} / \mathrm{D}$
\end{tabular}




\begin{tabular}{|c|c|}
\hline J uly 1995 & $26.8 \mathrm{~B} / \mathrm{D}$ \\
\hline A uqust 1995 & $25.2 \mathrm{~B} / \mathrm{D}$ \\
\hline September 1995 & $24.8 \mathrm{~B} / \mathrm{D}$ \\
\hline October 1995 & $24.4 \mathrm{~B} / \mathrm{D}$ \\
\hline November 1995 & $24.4 \mathrm{~B} / \mathrm{D}$ \\
\hline December 1995 & $26.3 \mathrm{~B} / \mathrm{D}$ \\
\hline J anuary 1996 & $28.0 \mathrm{~B} / \mathrm{D}$ \\
\hline February 1996 & $29.2 \mathrm{~B} / \mathrm{D}$ \\
\hline M arch 1996 & $27.2 \mathrm{~B} / \mathrm{D}$ \\
\hline A pril 1996 & $26.7 \mathrm{~B} / \mathrm{D}$ \\
\hline M ay 1996 & $26.6 \mathrm{~B} / \mathrm{D}$ \\
\hline J une 1996 & $24.9 \mathrm{~B} / \mathrm{D}$ \\
\hline July 1996 & $25.4 \mathrm{~B} / \mathrm{D}$ \\
\hline A ugust 1996 & $26.5 \mathrm{~B} / \mathrm{D}$ \\
\hline September 1996 & $26.1 \mathrm{~B} / \mathrm{D}$ \\
\hline October 1996 & $27.1 \mathrm{~B} / \mathrm{D}$ \\
\hline November 1996 & $26.4 \mathrm{~B} / \mathrm{D}$ \\
\hline December 1996 & $27.8 \mathrm{~B} / \mathrm{D}$ \\
\hline J anuary 1997 & $26.9 \mathrm{~B} / \mathrm{D}$ \\
\hline February 1997 & $26.9 \mathrm{~B} / \mathrm{D}$ \\
\hline M arch 1997 & $27.5 \mathrm{~B} / \mathrm{D}$ \\
\hline A pril 1997 & $26.3 \mathrm{~B} / \mathrm{D}$ \\
\hline M ay 1997 & $25.5 \mathrm{~B} / \mathrm{D}$ \\
\hline J une 1997 & $24.6 \mathrm{~B} / \mathrm{D}$ \\
\hline July 1997 & $23.5 \mathrm{~B} / \mathrm{D}$ \\
\hline A ugust 1997 & $24.3 \mathrm{~B} / \mathrm{D}$ \\
\hline September 1997 & $23.8 \mathrm{~B} / \mathrm{D}$ \\
\hline October 1997 & $22.9 \mathrm{~B} / \mathrm{D}$ \\
\hline November 1997 & $23.5 \mathrm{~B} / \mathrm{D}$ \\
\hline December 1997 & $21.7 \mathrm{~B} / \mathrm{D}$ \\
\hline J anuary 1998 & $19.0 \mathrm{~B} / \mathrm{D}$ \\
\hline February 1998 & $18.3 \mathrm{~B} / \mathrm{D}$ \\
\hline M arch 1998 & $18.9 \mathrm{~B} / \mathrm{D}$ \\
\hline
\end{tabular}

Field operations will be continued.

\section{Task II.6 - Technology T ransfer}

\section{$\underline{\text { Summary of work in last quarter }}$}

Monthly meetings were conducted with personnel from the James Russell Petroleum, Inc., the Tertiary Oil Recovery Project and the Petroleum Technology Transfer Council attending.

Summary of planned work for next quarter 
The field will be visited by other operators from the are. 